www.jmscr.igmpublication.org

Impact Factor (SJIF): 6.379

Index Copernicus Value: 79.54

ISSN (e)-2347-176x ISSN (p) 2455-0450

crossrefDOI: https://dx.doi.org/10.18535/jmscr/v6i9.47

Journal Of Medical Science And Clinical Research

\title{
A Case Report of a Large Myoid Hamartoma of Breast
}

Authors

\section{Rajashri Kelkar, Priya Ahire, Mahendra S. Navare, Tanvi M. Shah*, Aditi Agrawal \\ Grant Medical College \& Sir JJ Group of hospitals, Mumbai}

*Corresponding Author

Dr Tanvi M Shah

107, Hilla towers, A- wing, Dr SS Rao road, Lalbaug, Mumbai 400012, India

Mob: 9967215979, Email: drtmshahgsite2512@gmail.com

\begin{abstract}
Breast hamartomas are uncommon breast tumours with unclear pathogenesis \& varied histological patterns resulting in under-diagnosis. Immune-histochemistry is a valuable tool in their diagnosis. We report the case of a large myoid hamartoma of breast. Based on our literature search this is the largest reported size of a myoid breast hamartoma that was successfully managed by enucleation.
\end{abstract}

Keywords: myoid hamartomas, immunohistochemistry.

\section{Introduction}

Breast hamartoma is an uncommon breast tumour that accounts for approximately $4.8 \%$ of all benign breast masses ${ }^{[1]}$. It contains lobular breast tissue involving various fibrous, fibrocystic and adipose tissues. The pathogenesis of hamartomas remains unclear and its diagnosis is underestimated by clinicians and pathologists. We report a case of an uncommon myoid hamartoma of breast.

\section{Case Presentation}

A 33 year old patient presented with a painless lump in left breast since 10 years, gradually increasing in size. There was no history of nipple retraction or nipple discharge. On examination she had a 15 x $10 \times 10 \mathrm{~cm}$ mobile well defined lump in the left breast, with smooth surface \& soft consistency. There was no palpable axillary, cervical or supra-clavicular lymphadenopathy \& the contralateral breast was unremarkable.

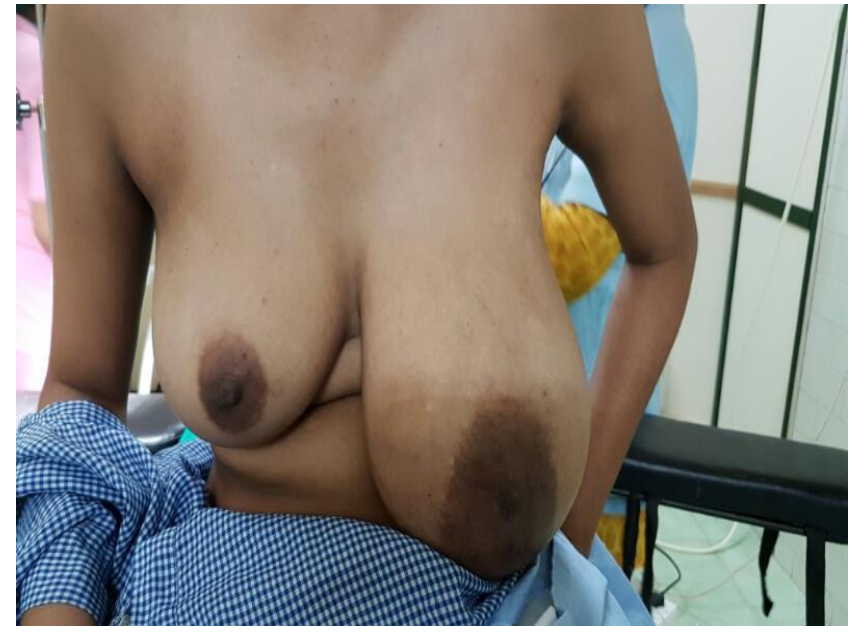

Biopsy of the lesion revealed hypo cellular lesion composed of bland spindle to epitheloid cells with abundant pink cytoplasm arranged in solid \& nest like patterns. Immunohistochemistry suggested smooth muscle proliferation (SMA \& desmin strongly positive \& weak expression of CD 34). Intra-operatively the lump was found to be well circumscribed \& was enucleated. 

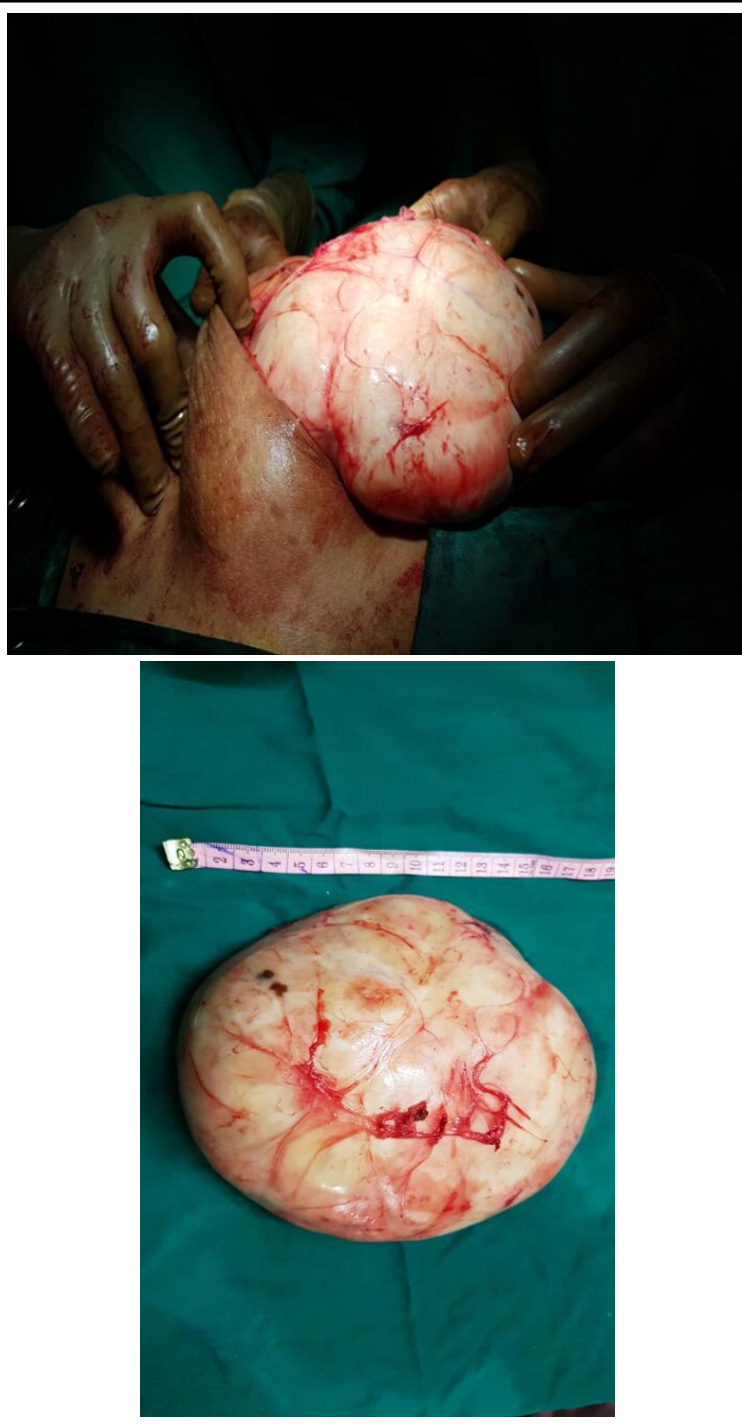

Final histopathology report revealed a well circumscribed lesion showing admixture of fibrous tissue, mature adipocytes, numerous smooth muscle bundles \& entrapped disordered lobules \& ducts suggestive of myoid hamartoma.

$\mathrm{H} \& \mathrm{E}$ section at $5 \mathrm{X}$, showing a circumscribed mass composed of adipose tissue smooth muscle and uniform ducts.

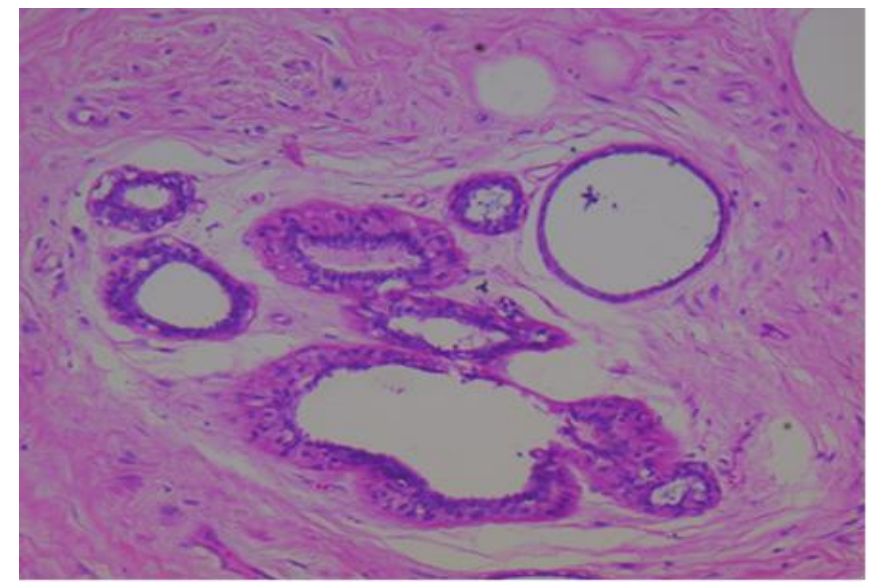

IHC- Smooth muscle seen (10x)

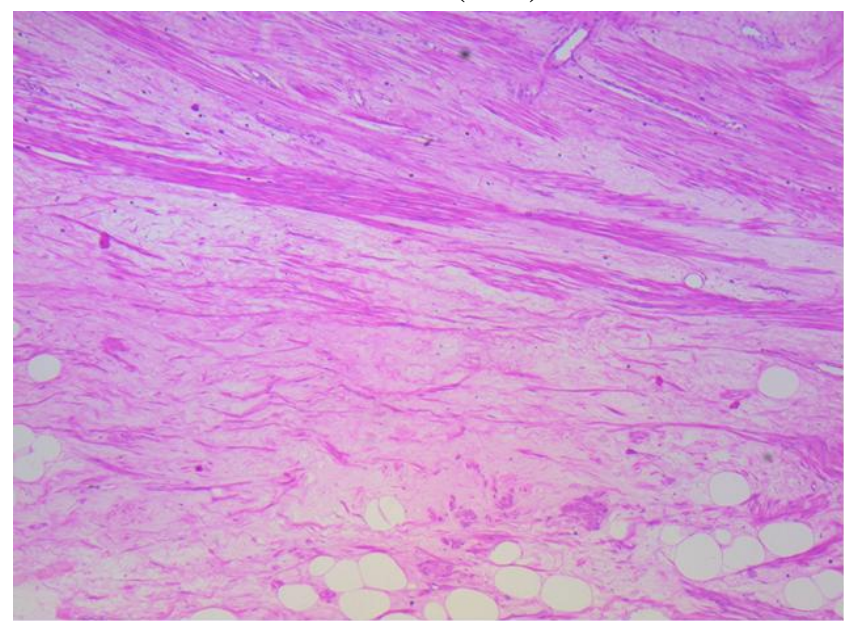

\section{Discussion}

Breast hamartomas are poorly defined, uncommon, benign breast neoplasms. The average age of the patients with breast hamartoma ranges between 33.5 and 66.5 years $^{[2,3,4,5,6,7]}$. They were initially defined as mastomas in 1928 by Prym ${ }^{[8]}$.

They are well circumscribed, mobile tumours not adherent to skin or muscle. Mammographic studies show a peripheral, lucent halo, and the mass is radiographically similar in pattern to a normal breast ("breast within a breast") ${ }^{[9]}$. Calcification is absent. USG evaluates breast hamartomas as having sono-lucent fat and a heterogeneous internal echo pattern with echogenic fibrous components ${ }^{[10]}$. MRI characteristically shows a smooth and welldefined hypointense rim, internal heterogeneous enhancement and the presence of fat density ${ }^{[7]}$.

Histologically, these encapsulated lesions are composed of various breast tissue components such as ducts, lobules, stroma prominently adipose, and smooth muscle, without any particular arrangement. The lobular distribution and the presence of fat in breast hamartomas are distinguishing features compared with fibroadenomas ${ }^{[11]}$. A fibrotic stroma surrounding the lobules and extending into the interlobular areas, causing obliteration, is the most frequently observed feature \& is often referred to as interlobular fibrosis ${ }^{[11,12,13]}$. Hamartoma is referred to as myoid hamartoma, a rarer form, when it shows a significant smooth muscle component. 
This term was first used by Davies and Riddell ${ }^{[14]}$ in 1973. Myoid hamartomas can reach large sizes. The sizes reported in a literature review range from $1.1 \mathrm{~cm}$ to $17 \mathrm{~cm}^{[15]}$

The etio-pathogenesis of breast hamartomas is not clear but they are thought to result from dysgenesis rather than a true tumorous process. However, female sex steroid hormones ${ }^{[7]}$ have been implicated in the development of breast hamartomas as demonstrated by estrogen receptor (ER) and progesterone receptor (PR) positivity in epithelial cells and stromal cells ${ }^{[6]}$. Additionally, there are no clear data on the source of smooth muscle for myoid hamartomas, but this muscle could derive from vessels, the nipples, undifferentiated breast stromal tissue or myoepithelial cells ${ }^{[16,17]}$. Another hypothesized smooth muscle source is the metaplasia of breast stromal cells ${ }^{[17]}$ into smooth muscle cells. The existence of CD34 on smooth muscles ${ }^{[7]}$ is an important sign of the metaplasia of stromal cells into smooth muscle cells. Myoid hamartomas stain strongly positive for SMA, desmin and vimentin by immunohistochemical staining.

The treatment of these lesion is surgical excision.

\section{Conclusion}

In conclusion, we present a case of a large myoid hamartoma, an uncommon benign breast tumour. Although breast hamartomas are rare, benign lesions, these lesions can reach large sizes. Based on our literature search this is the largest reported myoid hamartoma. A diagnosis can be made by core needle biopsy \& immunohistochemistry, along with an appropriate correlation of clinical and radiologic features. Breast hamartomas may be underdiagnosed because pathologists may categorize these lesions as fibroadenomas instead of hamartomas. Thus, the true incidence may be higher than the literature indicates. With more widespread use of newer imaging modalities \& availability of immunohistochemistry, more number of benign breast lump may be accurately identified as breast hamartomas.

\section{Sources of support- none \\ Conflicts of interest- none}

\section{References}

1. Charpin C, Mathoulin MP, Andrac L, Barberis J, Boulat J, Sarradour B, et al. Reappraisal of breast hamartomas. A morphological study of 41 cases. Pathol Res Pract. 1994; 190(4):362-71. [PubMed]

2. Ruiz-Tovar J, Reguero-Callejas ME, Arano-Bermejo JI, Gonzalez-Palacios F, Cabanas-Navarro L. [Mammary hamartoma] Cir Esp. 2006;79(3):186-8. [PubMed]

3. Filho OG, Gordan AN, Mello Rde A, Neto CS, Heinke T. Myoid hamartomas of the breast: report of 3 cases and review of the literature. Int J Surg Pathol. 2004; 12(2):151-3. [PubMed]

4. Lee EH, Wylie EJ, Bourke AG, Bastiaan De Boer W. Invasive ductal carcinoma arising in a breast hamartoma: two case reports and a review of the literature. Clin Radiol. 2003; 58(1):80-3. [PubMed]

5. Tse GM, Law BK, Pang LM, Cheung HS. Ductal carcinoma in situ arising in mammary hamartoma. J Clin Pathol. 2002; 55(7):541-2. [PMC free article] [PubMed]

6. Herbert M, Sandbank J, Liokumovich P, Yanai O, Pappo I, Karni T, et al. Breast hamartomas: clinicopathological and immunohistochemical studies of 24 cases. Histopathology. 2002; 41(1):30-4. [PubMed]

7. Wahner-Roedler DL, Sebo TJ, Gisvold JJ. Hamartomas of the breast: clinical, radiologic, and pathologic manifestations. Breast J. 2001; 7(2):101-5. [PubMed]

8. Prym P. Pseudoadenome, Adenome und Mastome der weiblithen Brustdrfise; Studien fiber die Entstehung umschriebener adenom $\sim$ hnlicher Herde in der Mamma und fiber die Nachahmung der Brustdrfisengewebes durch echte 
Adenome und Fibroadenome. Beitr Pathol Anat. 1928; 81:1-44.

9. Hamartoma of the breast; Dr Manuel Riveros MD, Antonio Cubilla MD, Francisco Perotta MD, Victor Solalinde MD; First published: November 1989

10. Kopans DB. Pathologic, mammographic and sonographic correlation. In: Kopans D B, editor. Breast Imaging. 2nd ed. Boston, Massachusetts: Lippincott-Raven; 1998. pp. 558-560.

11. Fechner RE. Fibroadenoma and related lesions. In: Page D L, Anderson T J, editors. Diagnostic Histopathology of the Breast. Edinburgh: Churchill Livingstone; 1987. pp. 72-85.

12. Fisher CJ, Hanby AM, Robinson L, Millis RR. Mammary hamartoma - a review of 35 cases. Histopathology. 1992; 20(2):99106. [PubMed]

13. Jones MW, Norris HJ, Wargotz ES. Hamartomas of the breast. Surg Gynecol Obstet. 1991; 173(1):54-6. [PubMed]

14. Davies JD, Riddell RH. Muscular hamartomas of the breast. J Pathol. 1973; 111(3):209-11. [PubMed]

15. [Breast hamartoma: a clinicopathologic analysis of 27 cases and a literature review: Yusuf Sevim,I Akin Firat Kocaay, II Tevfik Eker,II Haydar Celasin,III Ayca Karabork, IV Esra Erden,IV and Volkan GencII. Clinics (Sao Paulo). 2014 Aug; 69(8): 515-523. doi: 10.6061/clinics/2014(08)03 PMCID: PMC4129555, PMID: 25141109

16. Altermatt HJ, Gebbers JO, Laissue JA. Multiple hamartomas of the breast. Appl Pathol. 1989; 7(2):145-8. [PubMed]

17. Kajo K, Zubor P, Danko J. Myoid (Muscular) Hamartoma of the Breast: Case Report and Review of the Literature. Breast Care (Basel) 2010; 5(5):331-4. [PMC free article] [PubMed] 